\title{
Pyogenic Streptococci - Danger of Re-emerging Pathogens
}

\author{
IZABELA SITKIEWICZ* and WALERIA HRYNIEWICZ \\ Department of Epidemiology and Clinical Microbiology, National Medicines Institute, Warsaw, Poland
}

Received 30 October 2010, accepted 25 October 2010

\begin{abstract}
$\beta$-hemolytic, pyogenic streptococci are classified according to type of major surface antigen into A (Streptococcus pyogenes), B (Streptococcus agalactiae), C (multiple species including Streptococcus dysagalactiae) and G (multiple species including Streptococcus canis) Lancefield groups. Group A Streptococcus causes each year hundreds of thousands deaths globally as a result of infections and post-infectional sequelae. An increasing number of severe, invasive infections is caused by selected, specialized pathogenic clones. Within the last 50 years, an increasing number of human infections caused by groups B, C and G Streptococcus (GBS, GCS, GGS) has been observed worldwide. GBS was first identified as animal pathogen but the spectrum of diseases caused by GBS quickly shifted to human infections. Groups C and G Streptococcus are still regarded mostly as animal pathogens, however, an increased number of severe infections caused by these groups is observed. The increasing number of human infections caused worldwide by GCS/GGS can be a sign of similar development from animal to human pathogen as observed in case of GBS and this group will gain much more clinical interest in the future. The situation in Poland regarding invasive infections caused by pyogenic streptococci is underestimated.
\end{abstract}

Key words: Streptococcus sp., GAS, GBS, GCS, GGS

\section{Background}

In the antibiotics era and with the development of vaccines, it was believed that bacterial infections could be easily managed, and prevented thanks to vaccination. However, the spread of antibiotic resistance and lack of vaccines for multiple pathogens have become a public health problem. Lack of efficient tools to combat infections promotes the emergence of strains that are more pathogenic, more difficult and expensive to eradicate.

Streptococci are major human and animal pathogens, divided into more than 40 species and multiple groups whose taxonomy changed several times over the years (Kohler, 2007). This mini review will concentrate on $\beta$-hemolytic group of pyogenic streptococci and is intended to give a broad overview of the group, stress common aspects of their pathogenicity and point out the health cost of infections and economic aspects.

\section{Classification of Streptococcus}

Streptococcus is a genus that groups catalase negative, gram-positive cocci. Due to single and parallel division plane, they form chains composed of two or more cells. First classifications of streptococci, in addition to cell type and biochemical properties, were based on the type of hemolysis: $\alpha$ - reduction of hemoglobin, resulting in greenish zone around colonies; $\beta$ - complete lysis of erythrocytes and $\gamma$ - lack of visible hemolysis.

The pioneering work of Rebecca Craighill Lancefield in the early 1930s (Lancefield and Todd, 1928; Lancefield, 1933) systematized the classification of streptococci based on the presence and type of surface antigen: cell wall carbohydrate or lipoteichoic acids. The Lancefield classification differentiates well the $\beta$-hemolytic group and subdivides it further into groups labeled with capital letters from A through W. Some streptococci that exhibit $\alpha$ or $\gamma$ hemolysis, for example Streptococcus pneumoniae, do not encode Lancefield antigen. Major human streptococcal pathogens belong to so called "pyogenic" division of $\beta$-hemolytic streptococci and are classified as Lancefield groups A, B, C and G. For current and historic overview of classification of all streptococci see recent publications (Hardie and Whiley, 1997; Facklam, 2002; Kohler, 2007).

\section{Group A Streptococcus - a major player}

Streptococcus pyogenes belongs to Lancefield group A and is often called group A Streptococcus or simply GAS. Only a few other species such as Streptococcus dysagalactiae subsp. equisimilis, Streptococcus

\footnotetext{
* Corresponding author: I. Sitkiewicz, Department of Epidemiology and Clinical Microbiology, National Medicines Institute Chełmska 30/34, 00-725 Warsaw, Poland; e-mail: isitkiewicz@cls.edu.pl
} 
castoreus, Streptococcus anginosus, Streptococcus constellatus subsp. constellatus and Streptococcus orisratti can in very rare cases contain group antigen A (Kohler, 2007).

$S$. pyogenes is a causative agent of common suppurative, superficial infections of mucosal surfaces, skin and skin structures. The most common examples of GAS infections are streptococcal pharynghitis/tonsillitis, scarlet fever, impetigo, erysipelas, cellulitis, abscesses of various localization and pyoderma. However, in some cases these infections can lead to poststreptococcal non-suppurative sequelae as rheumatic fever, rheumatic heart diseases and glomerulonephritis. GAS is also able to cause severe, invasive, life threatening infections as streptococcal toxic shock syndrome (STSS), necrotizing fascitis (NF), rare cases of meningitis and pneumonia, puerperal sepsis and septicemia (for a review see (Cunningham, 2000) and references therein). Factors that predispose to invasive GAS infections are often related to immunological defects, metabolic diseases as diabetes, previous viral infections (chicken pox and influenza) and skin injuries (lesions, surgery, injecting drug use) (Lamagni et al., 2008).

GAS is recognized as one of the most important bacterial pathogens. Based on WHO data (Carapetis et al., 2005), it is estimated that GAS infections were in 2002 amongst the deadliest, just behind HIV, tuberculosis, malaria, pneumococcus, hepatitis B, Haemophilus influenzae type b, measles and rotavirus. Carapetis and co-workers (Carapetis et al., 2005), based on systematic analysis of GAS epidemiological data, estimate that GAS causes 616 million new cases of pharyngitis each year and number of existing cases of pyoderma is estimated to exceed 110 millions. In addition, the number of severe cases (both invasive infections and post-streptococcal sequelae) is estimated as at least 18.1 million of existing cases, with 1.78 million new cases each year that result in over half a million deaths each year globally.

Classification of GAS is based on the type of major surface antigen: protein M (serotyping) (Cunningham, $2000)$. In the past, $M$ type of the strain was determined using immunological reactions; recently most of the laboratories use sequencing of variable region of the gene encoding $\mathrm{M}$ protein (emm typing) (Johnson et al., 2006). So far, over $150 \mathrm{M}$ general serotypes (not including individual alleles of emm gene within each serotype) have been described (http:// www.cdc.gov/ncidod/biotech/strep/strepblast.htm).

The geographical distribution of $\mathrm{M}$ types varies, the most prevalent types in high income countries belong to M12, M1, M28, M4 and M3. Moreover, in these countries over $90 \%$ of all strains belong to 25 serotypes while remaining $10 \%$ groups over 145 se- rotypes (Steer et al., 2009). The distribution of strains in regions as Africa or Pacific region is remarkably different and 25 most prevalent serotypes contribute only $60 \%$ of all isolated serotypes (Steer et al., 2009). Serotypes isolated from invasive cases in Poland are very diverse on the molecular level but the majority of strains belong to serotype M1 (Szczypa et al., 2006). Currently, there is no commercially available vaccine that could prevent GAS infection. GAS is universally sensitive to penicillin and in cases of immediate allergy to penicillin, GAS infections are usually treated with macrolides as ertyhromycin. However, the increasing number of macrolide resistant strains in many parts of the world including Poland (Szczypa et al., 2004) can make the treatment more expensive and less efficient. Antibiotic treatment of invasive diseases is very often unsuccessful due to very rapid onset of the disease that results in death rate as high as $50 \%$. Based on success of pneumococcal vaccine (Whitney et al., 2003; Pletz et al., 2008; Isaacman et al., 2010) it seems that the future direction in management of GAS is elaboration of vaccine. Because infection with certain $M$ type does not protect from infection with other $\mathrm{M}$ types, formulation of currently tested vaccine is based on multiple M proteins (McNeil et al., 2005).

GAS virulence factors. Group A Streptococcus encodes a set of sophisticated virulence factors that are involved in multiple aspects of pathogenesis, from adhesion to intimate modulation of human immune system.

Initial contact between GAS and human host cells is achieved via interactions between bacterial adhesins and cell receptors as integrins, fibrinogen, collagen and extracellular matrix proteins (fibronectin, laminin, vitronectin) (Cunningham, 2000; Nobbs et al., 2009). Each strain of GAS encodes multiple, usually highly polymorphic, surface proteins that allows complex binding of host proteins (Nobbs et al., 2009).

The major adhesin and virulence factor of GAS is $\mathrm{M}$ protein. The protein has a very characteristic coiled coil structure with conserved cell wall anchored $\mathrm{C}$ terminus and hyper variable $\mathrm{N}$ terminal part (Cunningham, 2000; Bisno et al., 2003). Sequencing of the fragment encoding first 50 aa with 10 aa signal peptide is a base of molecular emm typing to determine serotype (Beall et al., 1996). $\mathrm{M}$ and M-like proteins are also involved in interaction between patogen and immune system (Perez-Caballero et al., 2004). They disrupt the classic complement cascade by binding of $\mathrm{C} 4 \mathrm{~b}$ factor and are able to disrupt the alternative cascade by binding factor $\mathrm{H}$ and factor $\mathrm{H}-$ like protein 1 (FHL-1) (PerezCaballero et al., 2004). M proteins also acts as antiphagocytic factor by physical blocking of complement binding (Carlsson et al., 2005) and is a potent 
inducer of inflammation upon binding Toll-like receptor 2 (Pahlman et al., 2006).

As a next step after initial contact, bacterial cells are released from the site and spread through tissues thanks to activity of multiple lytic enzymes. Host tissues are degraded by SpeB protease (Bohach et al., 1988; Chiang-Ni and $\mathrm{Wu}, 2008)$, host protease - plasmin, activated by streptokinase produced by GAS (Bergmann and Hammerschmidt, 2007) and hyaluronidase (Hynes et al., 2000).

In addition to host tissue degradation, GAS produces set of factors, including multiple proteases, involved in modulation of human immune response. $\mathrm{SpeB}$ protease cleaves component $\mathrm{C} 3 \mathrm{~b}$ of the complement and immunoglobulins (Collin and Olsen, 2003; Chiang-Ni and $\mathrm{Wu}, 2008$ ); ScpA protease cleaves human C5a complement component and slows influx of inflammatory cells to the site of infection (Ji et al., 1996); Mac/IdeS protease cleaves human IgG and blocks phagocyosis (Lei et al., 2001; von PawelRammingen et al., 2002); SpyCEP protease cleaves chemokines as IL-8, granulocyte chemotactic protein 2, growth-related oncogene alpha, macrophage inflammatory protein 2-alpha and growth-related protein beta (Edwards et al., 2005; Sumby et al., 2008; Kurupati et al., 2010); SIC blocks C5b-C9 complement complex (Akesson et al., 1996). GAS also developed strategy to evade response of innate immune system by production of DNAses that allow to escape neutrophil extracellular traps (Sumby et al., 2005a; Buchanan et al., 2006).

Third large group of GAS virulence factors is composed of multiple toxins as pore forming streptolysins S and O (Nizet, 2002), and superantigens that are also factors interacting with immune system (Fraser et al., 2000). Superantigens bind directly to MHC-II receptors and activate T-cells what leads to the uncontrolled release of pro-inflammatory cytokines (Fraser et al., 2000).

Selection of highly virulent clonal lineages. One of the most important aspects of multiple $\mathrm{M}$ types is non-random association of $\mathrm{M}$ type with manifestation of the disease. For example serotype M12 predominantly causes throat infections (Luca-Harari et al., 2009), while M3s are causing relatively more severe infections with higher mortality (Davies et al., 1996; Daneman et al., 2007), M18 serotype is correlated with rheumatic fever (Smoot et al., 2002a; Smoot et al., 2002b), and M28 serotype with puerperal sepsis (Green et al., 2005a; Green et al., 2005b).

The severity of the disease is associated with the emergence of particular lineages within certain serotypes that evolved as a result of acquisition of new genes/virulence factors that improve their fitness. The first well documented example of hyper virulent GAS clone is M1T1 lineage (Cleary et al., 1992). Strain classified as M1T1 are the most frequent isolated strains from severe invasive GAS infections (Aziz and Kotb, 2008). The unique features of M1T1 clone are related to the presence of $36 \mathrm{~kb}$ genomic island, prophages, acquisition of speA2 allele encoding superantigen SpeA and sdal encoding DNase (Aziz et al., 2005; Sumby et al., 2005b). The activity of Sda1 in particular was shown as major factor responsible for selection of highly virulent line (Walker et al., 2007).

Similar selection of virulent clone can be observed in case of M3 strains (Beres et al., 2002; Beres et al., 2004) where the process is also driven by acquisition of phage encoded new virulence factor - phospholipase A2 named SlaA (Sitkiewicz et al., 2006).

\section{Group B Streptococcus - Streptococcus agalactiae (GBS)}

Streptococcus agalactiae is classified as Lancefield group B (GBS). GBS is a major bovine pathogen that is one of the causes of bovine mastitis. Bovine infections still have big economic impact, as GBS might infect over $40 \%$ of the herd and influence milk quality and quantity (Keefe et al., 1997). GBS infecting humans was first isolated and described in 1930s in vaginal samples and samples from puerperal sepsis (Lancefield and Hare, 1935). Today, GBS colonizes gastrointestinal tract and genitourinary tract of about $30 \%$ of healthy individuals, without any symptoms (Badri et al., 1977; Foxman et al., 2006; van der MeeMarquet et al., 2008).

Until mid 1960s, human infections caused by GBS were described infrequently. However, from late 1960s to 1970 s GBS became predominant pathogen in neonates and children younger than 3 months (Phares et al., 2008). In children, GBS causes two major types of infections named early - and late onset disease. Early onset disease is caused by direct vertical transmission from colonized birth canal, usually develops within first few days of live and manifests as pneumonia, meningitis and/or sepsis. Fatality of early onset disease can be as high as 50\% (Shet and Ferrieri, 2004). Late onset disease can develop up to third month of live and direct mode of transmission is still unknown. The late onset disease manifests as sepsis, meningitis or osteomyelitis. In addition, GBS is able to cause infections of amniotic fluid during pregnancy and cause septic abortions (Daugaard et al., 1988; McDonald and Chambers, 2000). Following recommendations issued first by Centers for Disease Control in the United States (CDC, 2010) and later in many countries including Poland (Kotarski et al., 2008), the number of neonatal cases dropped in USA from 1.7 per 1000 live births in 1993 to 0.34 per 1000 live births in 2005. Unfortunately, antibiotic (penicillin) 
prophylaxis in pregnant individuals responsible for dramatic drop in early onset cases does not prevent late onset of the disease (Phares et al., 2008).

Like GAS, GBS is able to cause invasive diseases in non-pregnant individuals. The surveillance data shows that on the contrary to decline in neonatal infections, number of adult infections, especially among people older than 65 years, is high (25.3 cases per 100 000) (Phares et al., 2008). Adult infections in non-pregnant individuals are very often correlated with underlying medical conditions as diabetes mellitus, heart disease, cancer, obesity, neurologic disorders, immunosuppressive diseases etc. According to surveillance studies, $88 \%$ of adult cases have at least one underlying medical condition (Phares et al., 2008). Unfortunately, the success of penicillin treatment in GBS infection prevention and treatment delayed the development of GBS vaccine

GBS virulence factors. GBS virulence factors are less described than those of GAS, but similar classes of virulence factors can be distinguish in both pathogens. GBS encodes multiple adhesins responsible for interaction with eukaryotic cells: fibrin, fibrinogen and laminin binding proteins (Maisey et al., 2008); Srr (serine rich proteins) proteins that allow binding to keratin (Samen et al., 2007); surface pilli-like structures (Lauer et al., 2005); and large Alp/Rib family of adhesins that groups $\alpha \mathrm{C}(\mathrm{ACP}), \beta \mathrm{C}(\mathrm{BCP})$, epsilon/ Alp1, Alp2, Alp3, and Rib proteins (Bolduc et al., 2002; Baron et al., 2004; Creti et al., 2004). GBS also encodes pore forming toxins as hemolysin (Nizet, 2002). Production of hemolysin is correlated with the production of orange pigment protecting GBS from free radicals. Second pore forming toxin is called CAMP factor (Lang and Palmer, 2003) but its role in pathogenesis process remains unclear (Hensler et al., 2008). Finally, GBS produces set of factors that are involved in modulation of immune response as ScpB protease, homolog of GAS ScpA, that cleaves C5a component of complement (Bohnsack et al., 1997) and abolishes the activity of polymorphonuclear leukocytes (Takahashi et al., 1995). In addition, ScpB influences adhesion by cutting host proteins (Cheng et al., 2002). CspA encoded by GBS has similar sequence and function to SpyCEP (Harris et al., 2003). It cleaves fibrinogen and extracellular matrix proteins, but also degrades chemokines as growth-related oncogenes alpha, beta and gamma, granulocyte chemotactic protein 2 and neutrophil-activating peptide 2 , but on the contrary to GAS it does not cleave interleukin 8 (Bryan and Shelver, 2009).

Clonal structure of GBS population. Similarly to GAS, infections with GBS exhibit non random association with serotype, neonatal infections are predominantly caused by serotypes Ia and III, while infections in non pregnant adults are caused more frequently by serotypes Ib, II and V, with small percentage of infections caused by serotype III (Shet and Ferrieri, 2004).

Multiple studies on population structure of GBS conducted worldwide show that GBS infecting and colonizing humans has a highly clonal structure (Bohnsack et al., 2008; Springman et al., 2009). The clonal structure was also detected in Poland (Sadowy et al., 2010). Based on MLST (multi locus sequence typing) analysis, one particular clonal complex (CC 17) distinguished within serotype III is associated with neonatal invasive disease (Luan et al., 2005; Jones et al., 2006). Interestingly, analysis of population structure clearly shows the emergence of highly virulent human-associated $\mathrm{CC} 17$ complex from the bovine-associated CC67 (Sorensen et al., 2010).

\section{Groups C and G Streptococcus - an underestimated problem}

Groups C and G Streptococcus (GCS and GGS) are pathogens of animal origin, many are still classified as opportunistic pathogens. Similarly to GAS and GBS they can be carried by humans and are able to cause similar diseases as GAS, such as pharyngitis or impetigo. Human infections related to animal origin are often milk-borne and can have outbreak characteristics with severe complications as glomerulonephritis (Bordes-Benitez et al., 2006).

The classification of $\mathrm{C}$ and $\mathrm{G}$ groups of streptococci has changed over the last 40 years, and often various species designations are used by different authors. Bergey's Manual of Determinative Bacteriology from 1974, lists four species of group C Streptococcus: Streptococcus equisimilis, Streptococcus dysagalactiae, Streptococcus equi and Streptococcus zooepidermicus. However, some $S$. equisimilis strains contain the group $\mathrm{G}$ antigen. More recently, the introduction of subspecies was proposed to better distinguishes between Lancefield groups (Vandamme et al., 1996). S. equi was subdivided into $S$. equi subsp equi (GCS) and S. equi subsp zooepidermicus (GCS); and $S$. dysagalactiae was subdivided into $S$. dysagalactiae subsp dysagalactiae (GCS or rarely group L) and S. dysagalactiae subsp equisimilis. (GCS/GGS and rarely GAS or group L). The other species classified as GCS is Streptococcus canis.

Until the 1970s only rare cases of GCS/GGS invasive infections were described. For example, among 150000 blood cultures obtained at the Mayo Clinic from 1968 to 1977, only 8 revealed signs of GCS infection (Mohr et al., 1979). Multiple case reports from 1980-90s showed that most infected patients have some underlying diseases such as cardiovascular disease or malignancy, similar to GAS and GBS. In the case of GCS, the most common clinical manifestations were bacteremia and endocarditis, but also puerperal 
sepsis, pleuropulmonary infections, skin and softtissue infection, central nervous system infection, urinary tract infection, intra-abdominal abscess, epidural abscess, and dialysis-associated infection (Quevedo et al., 1987; Salata et al., 1989; Bradley et al., 1991; Marchandin et al., 2007).

In last 20 years an increase in number of human, invasive and often fatal diseases caused by GCS and GGS has been observed and GCS and GGS are being recognized as an important and emerging pathogens (Brandt and Spellerberg, 2009). According to epidemiological data from 2003-2004, burden and death rate parallels that of GAS (XVII Lancefield International Symposium on Streptococci and Streptococcal Diseases, presentation 013.3 "Genotypic analysis of invasive, emm-typeable Streptococcus dysagalactiae subsp. equisimilis and Streptococcus canis" Sakota V. et al.) (Efstratiou, 1989; Efstratiou, 1997; Ikebe et al., 2010).

\section{GAS, GBS, GCS and GGS epidemiology in Poland}

Based on published epidemiological data, increasing number of severe infections caused by pyogenic streptococci is observed worldwide. In addition, selection of highly virulent clones and dangerous shift from zoonotic infections to humans should be carefully monitored. Therefore, there is constant need of surveillance to trace of sources of infections, clonality and antibiotic resistance spread.

The situation in Poland regarding invasive diseases caused by pyogenic streptococci is greatly underestimated. National Institute of Public Health (PZH) collects epidemiological data about infections in Poland (http://www.pzh.gov.pl/oldpage/epimeld/index_p. $\mathrm{html})$. Until 2008 only cases of scarlet fever and erysipelas caused by GAS and cases of bacterial non meningococcal meningitis (presumably caused by GBS) were required by law to be reported to the authorities. According to legislation changed in 2008, the reported data includes other invasive infections caused by GAS. Cases of invasive GBS infections in non pregnant adults and infections caused by GCS and GGS are not reported. Collection of strains causing invasive infections is not required by law. However, the material is often sent to reference and academic centers for microbiological evaluation.

Knowledge about infections caused by GAS and GBS in Poland and clonal structure of populations is mostly related to the ongoing activity of two research groups (Szczypa et al., 2004; Szczypa et al., 2006; Skoczynska et al., 2007; Brzychczy-Wloch et al., 2008; Strus etal., 2009a; Strus etal., 2009b; Brzychczy-Wloch et al., 2010; Sadowy et al., 2010). The rate of infections caused by GCS and GGS in Poland is currently not recognized.

\section{Literature}

Akesson P., A.G. Sjoholm and L. Bjorck. 1996. Protein SIC, a novel extracellular protein of Streptococcus pyogenes interfering with complement function. J. Biol. Chem. 271: 1081-1088.

Aziz R.K., R.A. Edwards, W.W. Taylor, D.E. Low, A. McGeer and M. Kotb. 2005. Mosaic prophages with horizontally acquired genes account for the emergence and diversification of the globally disseminated M1T1 clone of Streptococcus pyogenes. J. Bacteriol. 187: 3311-3318.

Aziz R.K. and M. Kotb. 2008. Rise and persistence of global M1T1 clone of Streptococcus pyogenes. Emerg. Infect. Dis. 14: 1511-1517.

Badri M.S., S. Zawaneh, A.C. Cruz, G. Mantilla, H. Baer, W.N. Spellacy and E.M. Ayoub. 1977. Rectal colonization with group B Streptococcus: relation to vaginal colonization of pregnant women. J. Infect. Dis. 135: 308-312.

Baron M.J., G.R. Bolduc, M.B. Goldberg, T.C. Auperin and L.C. Madoff. 2004. Alpha C protein of group B Streptococcus binds host cell surface glycosaminoglycan and enters cells by an actin-dependent mechanism. J. Biol. Chem. 279: 24714-24723.

Beall B., R. Facklam and T. Thompson. 1996. Sequencing emm-specific PCR products for routine and accurate typing of group A streptococci. J. Clin. Microbiol. 34: 953-958.

Beres S.B., G.L. Sylva, K.D. Barbian, B. Lei, J.S. Hoff, N.D. Mammarella, M.Y. Liu, J.C. Smoot, S.F. Porcella, L.D. Parkins, D.S. Campbell, T.M. Smith, J.K. McCormick, D.Y. Leung, P.M. Schlievert and J.M. Musser. 2002. Genome sequence of a serotype M3 strain of group A Streptococcus: phage-encoded toxins, the high-virulence phenotype, and clone emergence. Proc. Natl. Acad. Sci. USA 99: 10078-10083.

Beres S.B., G.L. Sylva, D.E. Sturdevant, C.N. Granville, M. Liu, S.M. Ricklefs, A.R. Whitney, L.D. Parkins, N.P. Hoe, G.J. Adams, D.E. Low, F.R. DeLeo, A. McGeer and J.M. Musser. 2004. Genome-wide molecular dissection of serotype M3 group A Streptococcus strains causing two epidemics of invasive infections. Proc. Natl. Acad. Sci. USA 101: 11833-11838. Bergmann S. and S. Hammerschmidt. 2007. Fibrinolysis and host response in bacterial infections. Thromb. Haemost. 98: 512-520.

Bisno A.L., M.O. Brito and C.M. Collins. 2003. Molecular basis of group A streptococcal virulence. Lancet Infect. Dis. 3: 191-200. Bohach G.A., A.R. Hauser and P.M. Schlievert. 1988. Cloning of the gene, speB, for streptococcal pyrogenic exotoxin type B in Escherichia coli. Infect. Immun. 56: 1665-7.

Bohnsack J.F., A. Whiting, M. Gottschalk, D.M. Dunn, R. Weiss, P.H. Azimi, J.B. Philips, 3rd, L.E. Weisman, G.G. Rhoads and F.Y. Lin. 2008. Population structure of invasive and colonizing strains of Streptococcus agalactiae from neonates of six U.S. Academic Centers from 1995 to 1999. J. Clin. Microbiol. 46: 1285-1291.

Bohnsack J.F., K. Widjaja, S. Ghazizadeh, C.E. Rubens, D.R. Hillyard, C.J. Parker, K.H. Albertine and H.R. Hill. 1997. A role for C5 and C5a-ase in the acute neutrophil response to group B streptococcal infections. J. Infect. Dis. 175: 847-855. Bolduc G.R., M.J. Baron, C. Gravekamp, C.S. Lachenauer and L.C. Madoff. 2002. The alpha C protein mediates internalization of group B Streptococcus within human cervical epithelial cells. Cell. Microbiol. 4: 751-758.

Bordes-Benitez A., M. Sanchez-Onoro, P. Suarez-Bordon, A.J. Garcia-Rojas, J.A. Saez-Nieto, A. Gonzalez-Garcia, I. Alamo-Antunez, A. Sanchez-Maroto and M. Bolanos-Rivero. 2006. Outbreak of Streptococcus equi subsp. zooepidemicus infections on the island of Gran Canaria associated with the consumption of inadequately pasteurized cheese. Eur. J. Clin. Microbiol. Infect. Dis. 25: 242-246. 
Bradley S.F., J.J. Gordon, D.D. Baumgartner, W.A. Marasco and C.A. Kauffman. 1991. Group C streptococcal bacteremia: analysis of 88 cases. Rev. Infect. Dis. 13: 270-280.

Brandt C.M. and B. Spellerberg. 2009. Human infections due to Streptococcus dysgalactiae subspecies equisimilis. Clin. Infect. Dis. 49: 766-772.

Bryan J.D. and D.W. Shelver. 2009. Streptococcus agalactiae CspA is a serine protease that inactivates chemokines. J. Bacteriol. 191: 1847-1854.

Brzychczy-Wloch M., T. Gosiewski, M. Bodaszewska, W. Pabian, M. Bulanda, P. Kochan, M. Strus and P.B. Heczko. 2010. Genetic characterization and diversity of Streptococcus agalactiae isolates with macrolide resistance. J. Med. Microbiol. 59: 780-786. Brzychczy-Wloch M., M. Strus, D. Pawlik, H. Machlarz, T. Gosiewski, A. Drzewiecki, K. Rytlewski, R. Lauterbach and P.B. Heczko. 2008. Increasing Streptococcus agalactiae colonization of pregnant women and newborns in south-eastern region of Poland (in Polish). Med. Dośw. Mikrobiol. 60: 5-12.

Buchanan J.T., A.J. Simpson, R.K. Aziz, G.Y. Liu, S.A. Kristian, M. Kotb, J. Feramisco and V. Nizet. 2006. DNase expression allows the pathogen group A Streptococcus to escape killing in neutrophil extracellular traps. Curr. Biol. 16: 396-400.

Carapetis J.R., A.C. Steer, E.K. Mulholland and M. Weber. 2005. The global burden of group A streptococcal diseases. Lancet Infect. Dis. 5: 685-694.

Carlsson F., C. Sandin and G. Lindahl. 2005. Human fibrinogen bound to Streptococcus pyogenes M protein inhibits complement deposition via the classical pathway. Mol. Microbiol. 56: 28-39. CDC. 2007. Prevention of perinatol group B streptococcal disease. Revised guidelines from CDC. MMWR Morb. Mortal. Wkly. Rep. 59: RRIO

Cheng Q., D. Stafslien, S.S. Purushothaman and P. Cleary. 2002. The group B streptococcal C5a peptidase is both a specific protease and an invasin. Infect. Immun. 70: 2408-2413.

Chiang-Ni C. and J.J. Wu. 2008. Effects of streptococcal pyrogenic exotoxin B on pathogenesis of Streptococcus pyogenes. J. Formos. Med. Assoc. 107: 677-685.

Cleary P.P., E.L. Kaplan, J.P. Handley, A. Wlazlo, M.H. Kim, A.R. Hauser and P.M. Schlievert. 1992. Clonal basis for resurgence of serious Streptococcus pyogenes disease in the 1980s. Lancet 339: 518-521.

Collin M. and A. Olsen. 2003. Extracellular enzymes with immunomodulating activities: variations on a theme in Streptococcus pyogenes. Infect. Immun. 71: 2983-2992.

Creti R., F. Fabretti, G. Orefici and C. von Hunolstein. 2004. Multiplex PCR assay for direct identification of group B streptococcal alpha-protein-like protein genes. J. Clin. Microbiol. 42: $1326-1329$

Cunningham M.W. 2000. Pathogenesis of group A streptococcal infections. Clin. Microbiol. Rev. 13: 470-511.

Daneman N., K.A. Green, D.E. Low, A.E. Simor, B. Willey, B. Schwartz, B. Toye, P. Jessamine, G.J. Tyrrell, S. Krajden, L. Ramage, D. Rose, R. Schertzberg, D. Bragg and A. McGeer. 2007. Surveillance for hospital outbreaks of invasive group A streptococcal infections in Ontario, Canada, 1992 to 2000. Ann. Intern. Med. 147: 234-241.

Daugaard H.O., A.C. Thomsen, U. Henriques and A. Ostergaard. 1988. Group B streptococci in the lower urogenital tract and late abortions. Am. J. Obstet. Gynecol. 158: 28-31.

Davies H.D., A. McGeer, B. Schwartz, K. Green, D. Cann, A.E. Simor and D.E. Low and Ontario Group A Streptococcal Study Group. 1996. Invasive group A streptococcal infections in Ontario, Canada. N. Engl. J. Med. 335: 547-554.

Edwards R.J., G.W. Taylor, M. Ferguson, S. Murray, N. Rendell, A. Wrigley, Z. Bai, J. Boyle, S.J. Finney, A. Jones, H.H. Russell, C. Turner, J. Cohen, L. Faulkner and S. Sriskandan. 2005.
Specific C-terminal cleavage and inactivation of interleukin- 8 by invasive disease isolates of Streptococcus pyogenes. J. Infect. Dis. 192: 783-790

Efstratiou A. 1989. Outbreaks of human infection caused by pyogenic streptococci of Lancefield groups C and G. J. Med. Microbiol. 29: 207-219.

Efstratiou A. 1997. Pyogenic streptococci of Lancefield groups $\mathrm{C}$ and $\mathrm{G}$ as pathogens in man. Soc. Appl. Bacteriol. Symp. Ser. 26 : 72S-79S.

Facklam R. 2002. What happened to the streptococci: overview of taxonomic and nomenclature changes. Clin. Microbiol. Rev. 15 613-630.

Foxman B., B. Gillespie, S.D. Manning, L.J. Howard, P. Tallman, L. Zhang and C.F. Marrs. 2006. Incidence and duration of group B Streptococcus by serotype among male and female college students living in a single dormitory. Am. J. Epidemiol. 163: 544-551.

Fraser J., V. Arcus, P. Kong, E. Baker and T. Proft. 2000. Superantigens - powerful modifiers of the immune system. Mol. Med. Today 6: 125-132.

Green N.M., S.B. Beres, E.A. Graviss, J.E. Allison, A.J. McGeer, J. Vuopio-Varkila, R.B. LeFebvre and J.M. Musser. 2005a. Genetic diversity among type emm 28 group A Streptococcus strains causing invasive infections and pharyngitis. J. Clin. Microbiol. 43 : 4083-4091.

Green N.M., S. Zhang, S.F. Porcella, M.J. Nagiec, K.D. Barbian, S.B. Beres, R.B. LeFebvre and J.M. Musser. 2005b. Genome sequence of a serotype M28 strain of group A Streptococcus: potential new insights into puerperal sepsis and bacterial disease specificity. J. Infect. Dis. 192: 760-770.

Hardie J.M. and R.A. Whiley. 1997. Classification and overview of the genera Streptococcus and Enterococcus. Soc. Appl. Bacteriol. Symp. Ser. 26: 1S-11S.

Harris T.O., D.W. Shelver, J.F. Bohnsack and C.E. Rubens. 2003. A novel streptococcal surface protease promotes virulence, resistance to opsonophagocytosis, and cleavage of human fibrinogen. J. Clin. Invest. 111: 61-70.

Hensler M.E., D. Quach, C.J. Hsieh, K.S. Doran and V. Nizet. 2008. CAMP factor is not essential for systemic virulence of Group B Streptococcus. Microb. Pathog. 44: 84-88.

Hynes W.L., A.R. Dixon, S.L. Walton and L.J. Aridgides. 2000. The extracellular hyaluronidase gene (hylA) of Streptococcus pyogenes. FEMS Microbiol. Lett. 184: 109-112.

Ikebe T., Y. Oguro, K. Ogata, C. Katsukawa, J. Isobe, T. Shima, R. Suzuki, H. Ohya, K. Tominaga, R. Okuno, Y. Uchitani, Y. Tada, N. Okabe and H. Watanabe. 2010. Surveillance of severe invasive group $\mathrm{G}$ streptococcal infections in Japan during 2002-2008. Jpn. J. Infect. Dis. 63: 372-375.

Isaacman D.J., E.D. McIntosh and R.R. Reinert. 2010. Burden of invasive pneumococcal disease and serotype distribution among Streptococcus pneumoniae isolates in young children in Europe: impact of the 7-valent pneumococcal conjugate vaccine and considerations for future conjugate vaccines. Int. J. Infect. Dis. 14: 197-209.

Ji Y., L. McLandsborough, A. Kondagunta and P.P. Cleary. 1996. C5a peptidase alters clearance and trafficking of group A streptococci by infected mice. Infect. Immun. 64: 503-510.

Johnson D.R., E.L. Kaplan, A. VanGheem, R.R. Facklam and B. Beall. 2006. Characterization of group A streptococci (Streptococcus pyogenes): correlation of M-protein and emm-gene type with T-protein agglutination pattern and serum opacity factor. J. Med. Microbiol. 55: 157-164.

Jones N., K.A. Oliver, J. Barry, R.M. Harding, N. Bisharat, B.G. Spratt, T. Peto and D.W. Crook. 2006. Enhanced invasiveness of bovine-derived neonatal sequence type 17 group B Streptococcus is independent of capsular serotype. Clin. Infect. Dis. 42: 915-924. 
Keefe G.P., I.R. Dohoo and E. Spangler. 1997. Herd prevalence and incidence of Streptococcus agalactiae in the dairy industry of Prince Edward Island. J. Dairy. Sci. 80: 464-470.

Kohler W. 2007. The present state of species within the genera Streptococcus and Enterococcus. Int. J. Med. Microbiol. 297: $133-150$.

Kotarski J., P.B. Heczko, R. Lauterbach, T. Niemiec, B. Leszczynska-Gorzelak and Polish Gynecological Society. 2008. Polish Gynecological Society's recommendations regarding diagnosis and prevention of Streptococcus agalactiae infection in pregnant women and newborns. Ginekol. Pol. 79: 221-223.

Kurupati P., C.E. Turner, I. Tziona, R.A. Lawrenson, F.M. Alam, M. Nohadani, G.W. Stamp, A.S. Zinkernagel, V. Nizet, R.J. Edwards and S. Sriskandan. 2010. Chemokine-cleaving Streptococcus pyogenes protease SpyCEP is necessary and sufficient for bacterial dissemination within soft tissues and the respiratory tract. Mol. Microbiol. 76: 1387-1397.

Lamagni, T. L., J. Darenberg, B. Luca-Harari, T. Siljander, A. Efstratiou, B. Henriques-Normark, J. Vuopio-Varkila, A. Bouvet, R. Creti, K. Ekelund, M. Koliou, R. R. Reinert, A. Stathi, L. Strakova, V. Ungureanu, C. Schalen and A. Jasir. 2008. Epidemiology of severe Streptococcus pyogenes disease in Europe. J. Clin. Microbiol. 46: 2359-2367.

Lancefield R.C. 1933. A serological differentiation of human and other groups of hemolytic streptococci. J. Exp. Med. 57: 571-595. Lancefield R.C. and R. Hare. 1935. The serological differentiation of pathogenic and non-pathogenic strains of hemolytic streptococci from parturient women. J. Exp. Med. 61: 335-349.

Lancefield, R. C. and E.W. Todd. 1928. Antigenic differences between matt hemolytic streptococci and their glossy variants. J. Exp. Med. 48: 769-790.

Lang S. and M. Palmer. 2003. Characterization of Streptococcus agalactiae CAMP factor as a pore-forming toxin. J. Biol. Chem. 278: 38167-38173.

Lauer P., C.D. Rinaudo, M. Soriani, I. Margarit, D. Maione, R. Rosini, A.R. Taddei, M. Mora, R. Rappuoli, G. Grandi and J.L. Telford. 2005. Genome analysis reveals pili in Group B Streptococcus. Science 309: 105.

Lei B., F.R. DeLeo, N.P. Hoe, M.R. Graham, S.M. Mackie, R.L. Cole, M. Liu, H.R. Hill, D.E. Low, M.J. Federle, J.R. Scott and J.M. Musser. 2001. Evasion of human innate and acquired immunity by a bacterial homolog of CD11b that inhibits opsonophagocytosis. Nat. Med. 7: 1298-1305.

Luan S.L., M. Granlund, M. Sellin, T. Lagergard, B.G. Spratt and M. Norgren. 2005. Multilocus sequence typing of Swedish invasive group B Streptococcus isolates indicates a neonatally associated genetic lineage and capsule switching. J. Clin. Microbiol. 43: 3727-3733.

Luca-Harari B., J. Darenberg, S. Neal, T. Siljander, L. Strakova, A. Tanna, R. Creti, K. Ekelund, M. Koliou, P.T. Tassios, M. van der Linden, M. Straut, J. Vuopio-Varkila, A. Bouvet, A. Efstratiou, C. Schalen, B. Henriques-Normark and A. Jasir. 2009. Clinical and microbiological characteristics of severe Streptococcus pyogenes disease in Europe. J. Clin. Microbiol. 47: $1155-1165$

Maisey H.C., K.S. Doran and V. Nizet. 2008. Recent advances in understanding the molecular basis of group B Streptococcus virulence. Expert. Rev. Mol Med. 10: e27.

Marchandin H., E. Jumas-Bilak, A. Boumzebra, D. Vidal, O. Jonquet and P. Corne. 2007. Fatal Streptococcus equi subsp. ruminatorum infection in a man. Emerg. Infect. Dis. 13: 1964-1966.

McDonald H.M. and H.M. Chambers. 2000. Intrauterine infection and spontaneous midgestation abortion: is the spectrum of microorganisms similar to that in preterm labor? Infect. Dis. Obstet. Gynecol. 8: 220-227.
McNeil S.A., S.A. Halperin, J.M. Langley, B. Smith, A. Warren, G.P. Sharratt, D.M. Baxendale, M.A. Reddish, M.C. Hu, S.D. Stroop, J. Linden, L.F. Fries, P.E. Vink and J.B. Dale. 2005. Safety and immunogenicity of 26-valent group A Streptococcus vaccine in healthy adult volunteers. Clin. Infect. Dis. 41: 1114-1122.

Mohr D.N., D.J. Feist J.A. Washington, 2nd and P.E. Hermans. 1979. Infections due to group C streptococci in man. Am. J. Med. 66: $450-456$.

Nizet V. 2002. Streptococcal beta-hemolysins: genetics and role in disease pathogenesis. Trends. Microbiol. 10: 575-580.

Nobbs A.H., R.J. Lamont and H.F. Jenkinson. 2009. Streptococcus adherence and colonization. Microbiol. Mol. Biol. Rev. 73: 407-450.

Pahlman L.I., M. Morgelin, J. Eckert, L. Johansson, W. Russell, K. Riesbeck, O. Soehnlein, L. Lindbom, A. Norrby-Teglund, R.R. Schumann, L. Bjorck and H. Herwald. 2006. Streptococcal $\mathrm{M}$ protein: a multipotent and powerful inducer of inflammation. J. Immunol. 177: 1221-1228.

Perez-Caballero D., I. Garcia-Laorden, G. Cortes, M.R. Wessels, S.R. de Cordoba and S. Alberti. 2004. Interaction between complement regulators and Streptococcus pyogenes: binding of $\mathrm{C} 4 \mathrm{~b}$-binding protein and factor $\mathrm{H} /$ factor $\mathrm{H}$-like protein 1 to $\mathrm{M} 18$ strains involves two different cell surface molecules. J. Immunol. 173: 6899-6904.

Phares C.R., R. Lynfield, M.M. Farley, J. Mohle-Boetani, L.H. Harrison, S. Petit, A.S. Craig, W. Schaffner, S.M. Zansky, K. Gershman, K.R. Stefonek, B.A. Albanese, E.R. Zell, A. Schuchat and S.J. Schrag. 2008. Epidemiology of invasive group B streptococcal disease in the United States, 1999-2005. Jama 299: 2056-2065.

Pletz M.W., U. Maus, N. Krug, T. Welte and H. Lode. 2008. Pneumococcal vaccines: mechanism of action, impact on epidemiology and adaption of the species. Int. J. Antimicrob. Agents. 32: 199-206.

Quevedo S.F., D.J. Mikolich, D.E. Humbyrd and A.E. Fisher. 1987. Pyogenic sacroiliitis caused by group G Streptococcus. Arthritis Rheum 30: 115.

Sadowy E., B. Matynia and W. Hryniewicz. 2010. Population structure, virulence factors and resistance determinants of invasive, non-invasive and colonizing Streptococcus agalactiae in Poland. J. Antimicrob. Chemother. 65: 1907-1914.

Salata R.A., P.I. Lerner, D.M. Shlaes, K.V. Gopalakrishna and E. Wolinsky. 1989. Infections due to Lancefield group C streptococci. Medicine (Baltimore) 68: 225-239.

Samen U., B.J. Eikmanns, D.J. Reinscheid and F. Borges. 2007. The surface protein Srr-1 of Streptococcus agalactiae binds human keratin 4 and promotes adherence to epithelial HEp-2 cells. Infect. Immun. 75: 5405-5414.

Shet A. and P. Ferrieri. 2004. Neonatal \& maternal group B streptococcal infections: a comprehensive review. Indian. J. Med. Res. 120: 141-150.

Sitkiewicz I., M.J. Nagiec, P. Sumby, S.D. Butler, C. CywesBentley and J.M. Musser. 2006. Emergence of a bacterial clone with enhanced virulence by acquisition of a phage encoding a secreted phospholipase A2. Proc. Natl. Acad. Sci. USA 103: 16009-16014.

Skoczynska A., M. Kadlubowski, I. Wasko, J. Fiett and W. Hryniewicz. 2007. Resistance patterns of selected respiratory tract pathogens in Poland. Clin. Microbiol. Infect. 13: 377-383. Smoot J.C., K.D. Barbian, J.J. Van Gompel, L.M. Smoot, M.S. Chaussee, G.L. Sylva, D.E. Sturdevant, S.M. Ricklefs, S.F. Porcella, L.D. Parkins, S.B. Beres, D.S. Campbell, T.M. Smith, Q. Zhang, V. Kapur, J.A. Daly, L.G. Veasy and J.M. Musser. 2002a. Genome sequence and comparative microarray analysis of serotype M18 group A Streptococcus 
strains associated with acute rheumatic fever outbreaks. Proc. Natl. Acad. Sci. USA 99: 4668-4673.

Smoot J.C., E.K. Korgenski, J.A. Daly, L.G. Veasy and J.M. Musser. 2002b. Molecular analysis of group A Streptococcus type emm 18 isolates temporally associated with acute rheumatic fever outbreaks in Salt Lake City, Utah. J. Clin. Microbiol. 40: $1805-1810$.

Sorensen U.B., K. Poulsen, C. Ghezzo, I. Margarit and M. Kilian. 2010. Emergence and Global Dissemination of HostSpecific Streptococcus agalactiae Clones. MBio 1.

Springman A.C., D.W. Lacher, G. Wu, N. Milton, T.S. Whittam, H.D. Davies and S.D. Manning. 2009. Selection, recombination, and virulence gene diversity among group B streptococcal genotypes. J. Bacteriol. 191: 5419-5427.

Steer A.C., I. Law, L. Matatolu, B.W. Beall and J.R. Carapetis. 2009. Global emm type distribution of group A streptococci: systematic review and implications for vaccine development. Lancet Infect. Dis. 9: 611-616.

Strus M., A. Drzewiecki, A. Chmielarczyk, A. Tomusiak, P. Romanek, K. Kosowski, P. Kochan, M. van der Linden, R. Lutticken and P.B. Heczko. 2009a. Microbiological investigation of a hospital outbreak of invasive group A streptococcal disease in Krakow, Poland. Clin. Microbiol. Infect.

Strus M., D. Pawlik, M. Brzychezy-Wloch, T. Gosiewski, K. Rytlewski, R. Lauterbach and P.B. Heczko. 2009b. Group B Streptococcus colonization of pregnant women and their children observed on obstetric and neonatal wards of the University Hospital in Krakow, Poland. J. Med. Microbiol. 58: 228-233.

Sumby P., K.D. Barbian, D.J. Gardner, A.R. Whitney, D.M. Welty, R.D. Long, J.R. Bailey, M.J. Parnell, N.P. Hoe, G.G. Adams, F.R. Deleo and J.M. Musser. 2005a. Extracellular deoxyribonuclease made by group A Streptococcus assists pathogenesis by enhancing evasion of the innate immune response. Proc. Natl. Acad. Sci. USA 102: 1679-1684.

Sumby P., S.F. Porcella, A.G. Madrigal, K.D. Barbian, K. Virtaneva, S.M. Ricklefs, D.E. Sturdevant, M.R. Graham, J. Vuopio-Varkila, N.P. Hoe and J.M. Musser. 2005b. Evolutionary origin and emergence of a highly successful clone of serotype M1 group A Streptococcus involved multiple horizontal gene transfer events. J. Infect. Dis. 192: 771-782.
Sumby, P., S. Zhang, A.R. Whitney, F. Falugi, G. Grandi, E.A. Graviss, F.R. Deleo and J.M. Musser. 2008. A chemokinedegrading extracellular protease made by group A Streptococcus alters pathogenesis by enhancing evasion of the innate immune response. Infect. Immun. 76: 978-985.

Szczypa K., E. Sadowy, R. Izdebski and W. Hryniewicz. 2004. A rapid increase in macrolide resistance in Streptococcus pyogenes isolated in Poland during 1996-2002. J. Antimicrob. Chemother. 54: 828-831.

Szczypa K., E. Sadowy, R. Izdebski, L. Strakova and W. Hryniewicz. 2006. Group A streptococci from invasive-disease episodes in Poland are remarkably divergent at the molecular level. J. Clin. Microbiol. 44: 3975-3979.

Takahashi S., Y. Nagano, N. Nagano, O. Hayashi, F. Taguchi and Y. Okuwaki. 1995. Role of C5a-ase in group B streptococcal resistance to opsonophagocytic killing. Infect. Immun. 63: 4764-4769. van der Mee-Marquet N., L. Fourny, L. Arnault, A.S. Domelier, M. Salloum, M.F. Lartigue and R. Quentin. 2008. Molecular characterization of human-colonizing Streptococcus agalactiae strains isolated from throat, skin, anal margin, and genital body sites. J. Clin. Microbiol. 46: 2906-2911.

Vandamme P., B. Pot, E. Falsen, K. Kersters and L.A. Devriese. 1996. Taxonomic study of Lancefield streptococcal groups C, G, and L (Streptococcus dysgalactiae) and proposal of S. dysgalactiae subsp. equisimilis subsp. nov. Int. J. Syst. Bacteriol. 46: 774-781. von Pawel-Rammingen U., B.P. Johansson and L. Bjorck. 2002. IdeS, a novel streptococcal cysteine proteinase with unique specificity for immunoglobulin G. Embo. J. 21: 1607-1615.

Walker M.J., A. Hollands, M.L. Sanderson-Smith, J.N. Cole, J.K. Kirk, A. Henningham, J.D. McArthur, K. Dinkla, R.K. Aziz, R.G. Kansal, A.J. Simpson, J.T. Buchanan, G.S. Chhatwal, M. Kotb and V. Nizet. 2007. DNase Sda1 provides selection pressure for a switch to invasive group A Streptococcal infection. Nat. Med. 13: 981-985.

Whitney C.G., M.M. Farley, J. Hadler, L.H. Harrison, N.M. Bennett, R. Lynfield, A. Reingold, P.R. Cieslak, T. Pilishvili, D. Jackson, R.R. Facklam, J.H. Jorgensen and A. Schuchat. 2003. Decline in invasive pneumococcal disease after the introduction of protein-polysaccharide conjugate vaccine. N. Engl. J. Med. 348: 1737-46. 